\title{
PRACTICE OF SMALL AND MEDIUM-SIZED ENTERPRISE PERFORMANCE EVALUATION IN LATVIA
}

\author{
Inta Kotane \\ Rezekne Academy of Technologies, Latvia \\ Riga International School of Economics and Business Administration, Latvia
}

\begin{abstract}
The total number of small and medium-sized enterprises signifies an essential share of the national economy; SMEs' importance is evaluated by the value added and the new jobs created. Despite the growing research interest in the small and medium business performance measurement, there is no consistent opinion among researchers regarding small and medium business performance indicators, their measurement, and methods of assessment. The research study is based on an analysis of literature and scientific publications, the assessment of the financial indicators used by the Latvian institutions for the company's financial analysis, and an expert survey. The general scientific research methods are used in the research study: information analysis and synthesis, logical construction, monographic, an expert survey, data grouping, and the graphical method. The aim of the research - to carry out an analysis of the performance evaluation practice for small and medium-sized enterprises in Latvia. A study of the small and medium sized business performance measurement and management is carried out and the analysis of the financial indicators used for the performance measurement of small and medium-sized enterprises is performed in the result.
\end{abstract}

Keywords: financial indicators, small and medium-sized enterprises, business performance.

\section{Introduction}

In Latvia, small and medium-sized enterprises (SMEs) have a significant share of the total number of enterprises; they have an essential role in contributing to the gross domestic product and increasing the employment rate. In 2014, the average number of SMEs as a \% of the total number of enterprises in the European Union (EU) and in Latvia was 99.8\%. SMEs employed on average $66.9 \%$ of all private sector employees in the EU and $78.6 \%$ in Latvia in 2014. On average, SMEs produced $57.8 \%$ of the value added in the EU and $68.8 \%$ in Latvia (SBA Fact Sheet. Latvia, 2015). It is evident that the share of the people employed in SMEs in Latvia was by 11.7 percentage points above and the share of output by SMEs by 11 percentage points above the EU average. Overall, the SMEs have an important role in the economy of the EU and Latvia.

Foreign researchers encourage to include both financial and non-financial measurements in SMEs performance evaluation (Bianchi et al., 2013; Watts \& McNair-Connolly, 2012). 
The research results on SMEs performance (Sousa et al., 2006; Alver \& Branten, 2011; Saunila \& Ukko, 2011; Keh et. al. 2007) confirm that there are problems in the practical application of indicators, since there is no consistent approach to the identification, measurement, and assessment of financial and non-financial performance indicators.

Despite the fact that the number of publications on the given topic in the scientific literature increases, there is no single opinion among the researchers on the business performance indicators, their measurement, and assessment methods.

The aim of the research is to analyse the practice of the SMEs performance evaluation in Latvia. The object of the research is the assessment of the financial indicators used in SMEs performance evaluation.

The research is carried out based on the analysis of the literature and scientific publications, the assessment of the financial indicators used by the Latvian institutions for the company's financial analysis, and the expert survey.

The general scientific research methods are used in the research: analysis and synthesis, logical construction, monographic, an expert survey, data grouping, and the graphical method.

\section{Measurement and management of SMEs performance}

SMEs are considered to be a backbone of economic growth; they contribute to the provision of job opportunities, act as suppliers of goods and services for large enterprises. SMEs are characterized by a number of factors and criteria: location, size, age, structure, organization, number of employees, sales volume, asset value, use of innovation and technologies (Rahman, 2001). SMEs can be described as catalysts of the future economy; hence, it is necessary to accelerate the growth of the SMEs and to improve their competitiveness (Forsman, 2008).

The Bolton Committee established in the UK (1971) has formulated definitions of ,economy” and „statistics” of a small enterprise (Tonge, 2001). According to the definition of economy, an enterprise may be considered a small if it meets three criteria: 1) it has a relatively small market share; 2) it is personally run by the owner or co-owner without a mediation of formal management structure; and 3) it is independent and is not a part of a larger company. The "statistics" definition stipulated that the size of a company was determined by the market share and intensity of the competition in the sector.

The subsequent research studies (Storey, 1994; Atkinson \& Meagher, 1994) had pointed out the contradictions of the definitions of economy and statistics regarding the owner's ability to manage the company with more than 100 employees on his own, without management structures, as well as regarding 
the possibilities to influence the level of market price and to get higher profits with a relatively small market share.

It should be noted that similar SME criteria do not exist in the world. For instance, in the US, it is officially defined that SMEs are enterprises employing between 1 to 500 people. A company corresponds to the small business category if it employs up to 100 workers; it corresponds to the micro-business category if it employs up to 20 workers (Fadahunsi, 2012).

In 1996, the European Commission (EC) adopted the Recommendation 96/280/EC that established the first united definition of SME. The criteria to be used to identify the category of company are number of employees and annual turnover or book value (2003/361/EC). In Latvia, the definition of SME, or business category, is determined by the Regulations of the Cabinet of Ministers of December 16, 2014 (Kārtība, kādā komercsabiedrības deklarē ..., 2014) in accordance with Article 2 of Appendix 1 of the EU Regulation No.651/2014 of June 17, 2014 (Commission Regulation (EU) No 651/2014).

The general guidelines of the Council of Europe regarding small businesses are provided in the European Charter for Small Enterprises: the small businesses are the backbone of the European economy (European Charter for Small Enterprises..., 2000). Latvia joined the European Charter for Small Enterprises on April 23, 2002. The charter stipulates that small enterprises are recognized to be a crucial driving force for the promotion of entrepreneurship, employment, as well as the social and local integration of Europe. Although the European Charter for Small Enterprises was adopted by the Council of Europe in 2000, the principles and lines of action are still vital in 2016, confirming the existence of a number of unresolved issues in the promotion of small business development.

The author, exploring the theoretical aspects of business performance measurement and management (Kotāne, 2015), has concluded that the interest about the performance measurement and management issues has increased during the last two decades; the first studies on SME performance measurement occurred in the second half of the 1990s. In the early 2000s, the SME performance measurement studies were carried out in two directions: (1) adaptation of the performance measurement models designed for large companies and (2) development of specific models for SMEs.

The researchers' opinions on the SME performance measurement differ. There is a view that the majority of SMEs poorly apply performance measurement systems due to the lack of capital and labour resources, stiff competition, and the lack of awareness about the advantages of performance measurement (Barnes et al., 1998; Garengo et al., 2005). SMEs pay more attention particularly to the financial indicators (Massalla, 1994; Monkhouse, 
$1995)$ relying mainly on the accounting information and financial measurements (Carpinetti et al., 2008).

The author, assessing the SME performance measurement and management frameworks and the performance measurement practices in SMEs (Garengo et al., 2005; Jamil \& Mohamed, 2011; Phihlela \& Odunaike, 2012; Taticchi et al, 2008; Cocca \& Alberti, 2010; Bianchi et al, 2013; Olaru et al, 2014), has concluded that the course towards merging the financial and non-financial performance perspectives can be observed. However, despite the foreign practices, in Latvia, the assessment of SMEs performance can be carried out using only financial indicators.

\section{Financial indicators of SMEs performance evaluation}

Financial performance measurement is a commonly recognized process in the company's management (Chousa \& Castro, 2006), because the financial measurements provide important information for investors, financial analysts, auditors, and management, and they are easier to understand (Upadhaya et al., 2014).

Financial indicators used in the research studies on business performance evaluation (Wen et al., 2008; Phillips \& Louvieris, 2005; Fernandes et al., 2006; Cardinaels et al., 2010; Shi \& Yu, 2013) demonstrate their diversity.

The author believes that, in order to recognize and to assess the significance and role of financial indicators for the effective solving of the company's financial management issues, the problem of establishing a common financial indicator evaluation system for business performance evaluation has to be actuated.

Further, the author will assess the financial indicators used in the business financial performance analysis of Latvian companies, in order to obtain information on the practices of enterprise financial performance assessment in Latvia.

In Latvia, the information about companies' finances can be found in the databases and portals of three institutions: the Central Statistical Bureau of the Republic of Latvia (LR CSB), the „Lursoft” Ltd database, and the CrediWeb portal. The databases are diverse: the LR CSB provides summarised information about companies in general and by the type of activity (Statistics Database (2016); „Lursoft” Ltd provides an opportunity to evaluate the efficiency of potential cooperation partners, competitors, as well as of the own company (Analytical services, 2016); The CrediWeb portal offers online access to the company database in Latvia, providing its clients with the latest information and changes that are being updated at the moment of their registration (CrediWeb products and services, 2016). 
The financial indicators used by the LR CSB, „Lursoft” Ltd and CrediWeb for the company's financial analysis are shown in Table 1.

Table 1 Financial ratios used for companies' financial analysis (author's construction based on the Report on the company, 2016, Financial Analysis, 2016, Statistics Database, 2016)

\begin{tabular}{|c|c|c|}
\hline LR CSB & „Lursoft” Ltd & CrediWeb portal \\
\hline \multirow{2}{*}{ Assets turnover ratio } & Accounts receivable turnover, days \\
\cline { 2 - 3 } & \multicolumn{2}{|c|}{ Payables turnover, days } \\
\cline { 2 - 3 } & Current ratio \\
\hline \multicolumn{3}{|c|}{ Quick ratio } \\
\hline Cash ratio Debt-to-equity ratio & - \\
\hline Debt ratio & Gross profitability \\
\hline Short-term debt ratio & Return on assets (ROA) \\
\hline- & - & Return on sales (ROS) \\
\hline
\end{tabular}

The author has highlighted the financial ratios that are jointly used for companies' financial analysis. According to Table 1, it can be concluded that the same three financial ratios for the company's financial analysis are used by all the three above mentioned institutions: current ratio, total debt/ equity ratio, and return on assets ratio. Other financial ratios, except for the total assets turnover ratio, the cash ratio, and short-term debt in the balance ratio, are used by at least two of the aforementioned institutions.

The issue about the development of the specific financial indicators system, which could be used to effectively manage the company's financial situation, is essential to all Latvian enterprises and, particularly, to SMEs. The development of the financial indicators evaluation system is important not only to companies but as well to the government, since these indicators are the basis for comparative analyses by economic sectors and for analytical reports on the financial situation in the country.

Within the research, the expert survey was carried out; five industry experts were interviewed in order to assess the significance of the financial indicators used in financial analysis for the SMEs performance evaluation and to rank them according to the significance on a scale from 1 (the most significant indicator, or priority No. 1 in the SMEs performance evaluation) up to 14 (the least significant indicator, or priority No. 14). The criteria for the experts' selection were the level of their education (experts $\mathrm{C}$ and $\mathrm{D}$ were holding a master degree in Economics, experts $\mathrm{A}, \mathrm{B}$ and $\mathrm{E}-\mathrm{a}$ doctoral degree in Economics), and 
academic and/or professional experience in the field (each of the experts - more than 10 years of experience). Results of the expert discussion are summarized in Table 2.

Table 2 Results of the experts' evaluation

(author's calculations based on the data obtained in February 2016)

\begin{tabular}{|c|c|c|c|c|c|c|c|c|c|}
\hline \multirow{3}{*}{ Financial ratios } & \multicolumn{5}{|c|}{ Experts } & \multirow{3}{*}{ 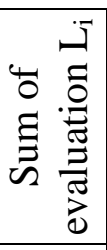 } & \multirow{3}{*}{ 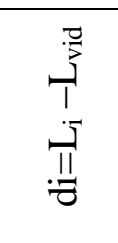 } & \multirow{3}{*}{$\operatorname{di} 2$} & \multirow{3}{*}{ 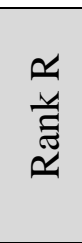 } \\
\hline & A & $\mathrm{B}$ & $\mathrm{C}$ & $\mathrm{D}$ & $\mathrm{E}$ & & & & \\
\hline & \multicolumn{5}{|c|}{ Evaluation } & & & & \\
\hline Current ratio & 7 & 11 & 13 & 5 & 14 & 50 & 12,5 & 156.25 & 12 \\
\hline Cash ratio & 10 & 10 & 11 & 14 & 13 & 58 & 20,5 & 420.25 & 13 \\
\hline Quick ratio & 14 & 6 & 12 & 6 & 11 & 49 & 11,5 & 132.25 & 10,5 \\
\hline Assets turnover, times & 13 & 5 & 8 & 13 & 10 & 49 & 11,5 & 132.25 & 10,5 \\
\hline Accounts receivable turnover, days & 2 & 8 & 6 & 3 & 7 & 26 & $-11,5$ & 132.25 & 4 \\
\hline Accounts payable turnover, days & 4 & 9 & 7 & 4 & 8 & 32 & $-5,5$ & 30.25 & 6 \\
\hline Inventory turnover, days & 9 & 7 & 5 & 10 & 9 & 40 & 2,5 & 6.25 & 7 \\
\hline Debt-to-equity ratio & 8 & 14 & 14 & 11 & 12 & 59 & 21,5 & 462.25 & 14 \\
\hline Debt ratio/ Equity ratio & 12 & 13 & 9 & 7 & 6 & 47 & 9,5 & 90.25 & 9 \\
\hline Short-term debt ratio in balance & 5 & 12 & 10 & 12 & 5 & 44 & 6,5 & 42.25 & 8 \\
\hline Gross profitability & 3 & 4 & 2 & 8 & 2 & 19 & $-18,5$ & 342.25 & 3 \\
\hline Return on assets (ROA) & 11 & 1 & 3 & 9 & 4 & 28 & $-9,5$ & 90.25 & 5 \\
\hline Return on equity (ROE) & 6 & 3 & 4 & 2 & 3 & 18 & $-19,5$ & 380.25 & 2 \\
\hline Return on sales (ROS) & 1 & 2 & 1 & 1 & 1 & 6 & $-31,5$ & 992.25 & 1 \\
\hline $\mathrm{n}=14$ & & & $\mathrm{~m}=5$ & & & $\begin{array}{l}\sum_{525} L_{i=} \\
525\end{array}$ & 0 & $\begin{array}{c}S=340 \\
9,5\end{array}$ & - \\
\hline
\end{tabular}

The expert opinions were measured by the degree of consensus of the views. In case of the direct parameter evaluation, the degree of consensus of the experts is assessed applying the coefficient of concordance- Kendall's W (Kendall, 1955) using Formula 1:

$$
W=\frac{12 \sum_{i=1}^{n}\left\{\sum_{j=1}^{m} r_{i j}-\frac{1}{2} m(n+1)\right\}^{2}}{m^{2}\left(n^{3}-n\right)}
$$

where, W - coefficient of concordance

$\mathrm{n} \quad-\quad$ number of objects to be ranked

$\mathrm{m}-$ number of experts

$\mathrm{r}_{\mathrm{ij}} \quad-\quad$ rank given to object $i$ by expert number $j$ 
The value of the coefficient of concordance can vary in the range $0 \leq \mathrm{W} \leq 1$; additionally, $\mathrm{W}=0$ if there is no correlation between the ranks, and $\mathrm{W}=1$ if all the experts have ranked objects equally. It is regarded that an adequate value of the coefficient of concordance is $\mathrm{W} \geq 0.50$ when it is considered that the expert consensus is adequately high (Kendall, 1955).

The computed coefficient of concordance $\mathrm{W}=0.6$ indicates that the experts have generally been united in their views and have unanimously recognized that the most significant financial indicators for the SMEs performance evaluation are as follows: return on sales (ROS), return on equity (ROE), gross profitability, receivables turnover (in days), return on assets (ROA), payables turnover (in days), and inventory turnover (in days).

A comparison of the financial indicators used by the institutions for the company's financial analysis (Table 1) and the financial indicators ranked by the experts (Table 2) leads to a conclusion that at least two institutions for the company's financial analysis use the same financial ratios indicated as the most important by the experts.

Further research on the use of financial indicators for the SMEs performance evaluation shall be focused on the importance of the indicators in accordance with the aim of the SMEs performance evaluation (financial analysis to attract investments; interest of owners, etc.).

\section{Conclusions}

1. The analysis of the SMEs performance measurement and management frameworks and the study on performance measurement practices point out that the direction towards merging the financial and non-financial performance perspectives can be observed. In Latvia, the assessment of SMEs performance can be carried out using only financial indicators.

2. The CSB of Latvia, "Lursoft" Ltd, and the CrediWeb portal equally use the same three financial ratios for the company's financial analysis: cash ratio, total debt/equity ratio, and return on assets ratio.

3. The experts have unanimously recognized that the most significant financial indicators for the SMEs performance evaluation are return on sales (ROS), return on equity (ROE), gross profitability, receivables turnover (in days), return on assets (ROA), payables turnover and inventory turnover (in days).

4. To identify and to assess the significance and the role of financial indicators for the effective solving of the company's financial management problems, it is necessary to develop a common financial indicators system for business performance evaluation. 


\section{References}

003/361/EC. Commission Recommendation of 6 May 2003 concerning the definition of micro, small and medium-sized enterprises (notified under document number C(2003) 1422). Official Journal of the European Union. Downloaded from http://eurlex.europa.eu/LexUriServ/LexUriServ.do?uri=OJ:L:2003:124:0036:0041:en:PDF

Alver, J., \& Branten, M. (2011). Measurement and analysis of profitability in estonian companies. Journal of International Scientific Publications: Economy \& Business, 5 (2). Downloaded from http://www.scientific-publications.net/download/economy-andbusiness-2011-2.pdf

Analytical Services (2016). SIA „Lursoft. Downloaded from http://www.lursoft.lv/ en/analytical-services

Atkinson, J., \& Meager, N. (1994). Running to stand still: the small business in the labour market. In Employment the small firm and the labour market (Ed.) J.Atkinson and D.J.Storey. London: Routledge.

Barnes, M., Coulton, L., Dickinson, T. Dransfield, S., Field, J., Fisher, N., Saunders, I., \& Shaw, D. (1998). New approach to performance measurement for small and medium enterprises. Downloaded from http://citeseerx.ist.psu.edu/viewdoc/download? doi=10.1.1.42.3859\&rep=rep1\&type $=$ pdf

Bianchi, C., Marinkovic, M., \& Cosenz, F. (2013). A Dynamic Performance Management Approach to Evaluate and Support SMEs Competitiveness: Evidences from a Case Study. In proceeding of: 31 st International Conference of the System Dynamics Society, USA

Cardinaels E., \& van Veen-Dirks P.M.G. (2010). Financial versus non-financial information: The impact of information organization and presentation in a Balanced Scorecard. Accounting, Organizations and Society, 5, 565-578.

Carpinetti, L.C.R., Galdámez, E.V.C., \& Gerolamo, M.C. (2008). A measurement system for managing performance of industrial clusters: A conceptual model and research cases. International Journal of Productivity and Performance Management, 57 (5), 405 - 419.

Chousa, J.P., \& Castro, N.B. (2006). Integrating Sustainability into Traditional Financial Analysis. Sustainability Accounting and Reporting, 21, 83-108.

Cocca, P., \& Alberti, M. (2010). A framework to assess performance measurement systems in SMEs. International Journal of Productivity and Performance management, 59 (2), 186.-200.

Commission Regulation (EU) No 651/2014 of 17 June 2014 declaring certain categories of aid compatible with the internal market in application of Articles 107 and 108 of the Treaty Text with EEA relevance. Downloaded from http://eur-lex.europa.eu/legalcontent/EN/TXT/PDF/?uri=CELEX:32014R0651\&from=EN

CrediWeb products and services (2016). CrediWeb portal. Downloaded from https://www.crediweb.lv/about/?_lang=en

European Charter for Small Enterprises (2000). European Commission. Downloaded from http://cordis.europa.eu/documents/documentlibrary/46982271EN6.pdf .

Fadahunsi, A. (2012). The Growth of Small Businesses: Towards A Research Agenda. American Journal of Economics and Business Administration, 4 (1), 105-115.

Fernandes, K.J., Raja, V., \& Whalley, A. (2006). Lessons from implementing the balanced scorecard in a small and medium size manufacturing organization. Technovation., 26, 623-634. 
Financial Analysis (2016). SIA „Lursoft”. Downloaded from http://www.lursoft.lv/en/ financial-analysis

Forsman, H. (2008). Business development success in SMEs: a case study approach. Journal of Small Business and Enterprise Development, 15 (3), 606 - 622.

Garengo, P., Biazzo, S., \& Bititci, U.S. (2005). Performance measurement systems in SMEs: A review for a research agenda. International Journal of Management Reviews, 7 (1), $25-47$.

Jamil, Z.M., \& Mohamed, R. (2011). Performance Measurement System (PMS) in Small Medium Enterprises (SMES): A Practical Modified Framework. World Journal of Social Sciences, 1 (3), 200.-212.

Kārtība, kādā komercsabiedrības deklarēe savu atbilstību mazās (sīkās) un vidējās komercsabiedrības statusam. (2014.g.16.dec.). MK noteikumi Nr.776. Pieejas veids http://m.likumi.lv/doc.php?id=271191

Keh, H.T., Nguyen, T.T.M., \& Ng, H.P. (2007). The effects of entrepreneurial orientation and marketing information on the performance of SMEs. Journal of Business Venturing, 22 (4), 592.-611.

Kendall, M.G. (1955). Rank Correlation Methods. New York, Hafner Publishing Co.

Kotāne, I. (2015). Theoretical Aspects of Measurement and Management of the Company's Performance. Latgales Tautsaimniecības pētījumi: Sociālo zinātņu žurnāls. 1 (7), 92.116. Downloaded from http://journals.ru.lv/index.php/LNRE/article/view/1181

Massalla, C. (1994). Designing a Performance Measurement System for a Small Company: A Case Study. Operations Strategy and Performance (EurOMA Conference Proceedings), University of Cambridge, Cambridge, 325-33O.

Monkhouse, E. (1995). The role of competitive benchmarking in small-to medium-sized enterprises. Benchmarking for Quality Management \& Technology, 2 (4), 41-50.

Olaru, M., Pirnea.I.C., Hohan, A., \& Maftei, M. (2014). Performance Indicators Used by SMEs in Romania, Related to Integrated Management Systems. Procedia - Social and behavioral Sciences, 109, 949.-953.

Phihlela, T.R., \& Odunaike, S.A. (2012). A Measurement Framework to Assess SME Performance. Proceedings of the International Systems Educators Conference, New Orleans Louisiana, USA.

Phillips P., \& Louvieris P. (2005). Performance measurement systems in tourism, hospitality and leisure small medium-sized enterprises: a balanced scorecard perspective. Journal of Travel Research, 44, 201-211.

Rahman, S. (2001). A comparative study of TQM practice and organisational performance of SMEs with and without ISO 9000 certification. International Journal of Quality \& Reliability Management, 18 (1), 35-49.

Report on the company (2016). CrediWebportal. Pieejas veids. Downloaded from https://www.crediweb.lv/about/services/sample/short_en.pdf

Saunila, M., \& Ukko, J. (2013). Facilitating innovation capability through performance measurement: A study of Finnish SMEs, Management Research Review, 36 (10), 991 1010.

SBA Fact Sheet. Latvia (2015). Downloaded from http://ec.europa.eu/growth/smes/businessfriendly-environment/performance-review/files/countries-sheets/2015/latvia_en.pdf

Shi, M., \& Yu, W. (2013). Supply chain management and financial performance: literature review and future directions. International Journal of Operations \& Production Management, 33 (10), 1283 - 1317. 
Sousa S.D., Aspinwall E.M., \& Rodrigues A.G. (2006). Performance measures in English small and medium enterprises: survey results. Benchmarking: An International Journal, $13(1 / 2), 120-134$.

Statistics Database (2016). LR CSB. Downloaded from http://www.csb.gov.lv/ en/dati/ statistics-database-30501.html

Storey, D.J. (1994). Understanding the small business sector. London: International Thomson Business Press.

Taticchi, P., Cagnazzo, L., \& Botarelli, M. (2008). Performance Measurement and Management (PMM) for SMEs: a literature review and a reference framework for PMM design. Annual Conference La Jolla.

Tonge, J. (2001). A Review of Small Business Literature. Part 1: Defining The Small Business. WPS025. Manchester Metropolitan University Business School Working Paper Series. Downloaded from http://www.ribm.mmu.ac.uk/wps/papers/01-18.pdf

Upadhaya, B., Munir, R., \& Blount, Y. (2014). Association between performance measurement systems and organisational effectiveness. International Journal of Operations \& Production Management, 34 (7), 853 - 875.

Watts, T., \& McNair-Connolly, C.J. (2012). New Performance Measurement and Management Control Systems. Journal of Applied Acounting Research, 13 (3), 226.241.

Wen, W., Chen, Y.H., \& Chen, I.C. (2008). A knowledge-based decision support system for measuring enterprise performance. Knowledge-Based Systems, 21 (2), 148.-163. 